DOI: 10.22630/EIOGZ.2014.106.13

Zeszyty Naukowe Szkoły Głównej Gospodarstwa Wiejskiego

Ekonomika i Organizacja Gospodarki Żywnościowej nr 106, 2014: 33-44

Serhiy Zabolotnyy

Katedra Ekonomiki i Organizacji Przedsiębiorstw

Szkoła Główna Gospodarstwa Wiejskiego w Warszawie

\title{
Wartość ekonomiczna w zależności od strategii płynności finansowej spółek akcyjnych z sektora agrobiznesu notowanych na Giełdzie Papierów Wartościowych w Warszawie
}

\section{Wstęp}

Rozwój przedsiębiorstwa w gospodarce rynkowej wiąże się z systematycznym pomnażaniem wartości dla właścicieli, co jest równoznaczne $\mathrm{z}$ maksymalizacją różnicy między wartością rynkową tego kapitału a jego aktualną wartością księgową [Wędzki 2003, s. 34]. Realizacja tego postulatu jest możliwa wyłącznie pod warunkiem utrzymania płynności finansowej, czyli zdolności do regulowania zobowiązań bieżących. Związek między wartością i płynnością finansową przedsiębiorstwa można przedstawić przez analizę głównych czynników tworzenia wartości, którymi są przepływy z działalności operacyjnej, stopa dyskontowa oraz zadłużenie [Rappaport 1999, s. 65]. W ujęciu teoretycznym kształtowanie przepływów z działalności operacyjnej oraz poziom zadłużenia przedsiębiorstwa w dużym stopniu zależą od sposobu zarządzania płynnością finansową: wzrost nakładów na majątek obrotowy prowadzi do ograniczenia przepływu pieniężnego, zwiększenie bieżących zobowiązań oddziałuje natomiast na wskaźnik zadłużenia firmy, wpływając pośrednio na koszt kapitału i stopę dyskontową dla przedsiębiorstwa. W związku z tym maksymalizowanie wartości firmy bez uwzględnienia kategorii płynności finansowej może prowadzić do wielu niekorzystnych zjawisk w obszarze rentowności oraz ryzyka finansowego, włącznie ze zwiększeniem prawdopodobieństwa bankructwa [Franc-Dąbrowska 2010, s. 55]. Ze względu na taką zależność zarządzający przedsiębiorstwami powinni wyznaczać i realizować odpowiednie strategie płynności finansowej, rozumiane jako kompleks zamierzeń 
i działań w zakresie zarządzania aktywami i pasywami bieżącymi [Wasilewski, Zabolotnyy 2009, s. 5]. Za nadrzędny cel takiej strategii należy uznać zapewnienie wzrostu wartości dla właścicieli poprzez kształtowanie odpowiedniego poziomu płynności finansowej [Sierpińska, Wędzki 1997, s. 11].

\section{Cel i metodyka badań}

Celem badań było określenie współzależności między strategią płynności finansowej a efektywnością spółek giełdowych z sektora agrobiznesu. Strategie płynności finansowej zdefiniowano za pomocą zagregowanego wskaźnika finansowego, obliczonego z zestawu zmiennych finansowych na podstawie metody liniowego porządkowania obiektów wielocechowych [StatSoft Polska 2009, s. 23]:

$$
W_{i}=100 \cdot \sum_{j=1}^{m} a_{j} x_{i j}
$$

gdzie:

$W_{i}$ - wskaźnik zagregowany,

$m$ - liczba zmiennych finansowych,

$a_{j}$ - waga $j$-tej zmiennej,

$x_{i j}$ - sumowane wartości wybranej zmiennej.

Doboru zmiennych dokonano na podstawie analizy eksperckiej w wyniku konsultacji z polskimi naukowcami. Normalizację zmiennych uwzględnionych w konstrukcji wskaźnika zagregowanego przeprowadzono na podstawie następujących wzorów:

$$
\text { dla stymulant } \rightarrow x_{i j}=\frac{x_{i j}-\min _{i}\left\{x_{i j}\right\}}{\max _{i}\left\{x_{i j}\right\}-\min _{i}\left\{x_{i j}\right\}}
$$

$$
\text { dla destymulant } \rightarrow x_{i j}=\frac{\max \left\{x_{i j}\right\}-x_{i j}}{\max _{i}\left\{x_{i j}\right\}-\min _{i}\left\{x_{i j}\right\}}
$$

gdzie:

$i$ - numer obiektu,

$j$ - numer zmiennej.

Odpowiednie wartości ekstremalne ( $\min$ i max) pochodziły ze zbioru obiektów dla zadanej zmiennej. 
Wynikiem zastosowania metody porządkowania liniowego było utworzenie dla każdego badanego roku listy rankingowej przedsiębiorstw w skali od 0 do 100 , ze względu na kryterium maksymalizacji płynności finansowej. Przedsiębiorstwa o mniejszej liczbie punktów charakteryzowały się bardziej agresywną strategią płynności finansowej, z kolei spółki o większej liczbie punktów - bardziej konserwatywną strategią. Do dalszej klasyfikacji całkowitej strategii płynności finansowej wykorzystano metodę kwartyli [Wasilewski, Zabolotnyy 2009, s. 177]. Kwartyle dzielą zbiorowość na cztery liczebnie równe części. Zgodnie z przyjętym założeniem, do strategii agresywnych należały spółki o wielkości wskaźnika zagregowanego poniżej kwartyla pierwszego (dolnego), strategie konserwatywne obejmowały natomiast przedsiębiorstwa o wskaźniku większym od kwartyla trzeciego (górnego). Przedsiębiorstwa znajdujące się pomiędzy kwartylem pierwszym a trzecim i stanowiące $50 \%$ liczby badanej populacji zaliczono do strategii umiarkowanych, charakteryzujących się przeciętnym nastawieniem na maksymalizację wartości dla właścicieli, przy umiarkowanym ryzyku utraty płynności finansowej.

Wartość ekonomiczną przedsiębiorstw oszacowano na podstawie wskaźników ekonomicznej wartości dodanej oraz pieniężnej wartości dodanej. Ekonomiczną wartość dodaną charakteryzującą korzyści dla właścicieli wyrażono następującym wzorem:

$$
E V A_{t}=N O P A T_{t}-W A C C_{t} \cdot I C_{t-1}
$$

gdzie:

$N O P A T_{t}$ - zysk operacyjny netto po opodatkowaniu w okresie $t$,

$W A C C_{t}$ - średni ważony koszt kapitału zainwestowanego w okresie $t$,

$I C_{t-1} \quad$ - zainwestowany kapitał na początek okresu.

Pieniężną wartość dodaną oszacowano na podstawie wzoru:

$$
C V A_{t}=G O P A T_{t}-W A C C \cdot G I_{t-1}
$$

gdzie:

$G O P A T_{t}$ - zysk operacyjny brutto po opodatkowaniu w okresie $t$, $G I_{t-1} \quad$ - kapitał zainwestowany brutto na początek okresu $t$.

Zysk operacyjny brutto obliczono jako sumę zysku operacyjnego netto po opodatkowaniu (NOPAT) oraz amortyzacji, kapitał zainwestowany brutto ustalono natomiast podobnie jak w przypadku $E V A$, z uwzględnieniem korekty o skumulowaną amortyzację. 
Do oszacowania kosztu kapitału własnego badanych przedsiębiorstw przyjęto założenia modelu CAPM:

$$
k_{E}=r_{R F}+\beta_{E} \cdot\left(r_{M}-r_{R F}\right)
$$

gdzie:

$k_{E}-$ koszt kapitału własnego,

$r_{R F}$ - stopa wolna od ryzyka,

$r_{M}$ - oczekiwana stopa zwrotu z inwestycji w tzw. portfel rynkowy, czyli portfel zbudowany ze wszystkich rodzajów aktywów będących przedmiotem obrotu na danym rynku kapitałowym; najczęściej jest to skład portfela indeksu giełdowego,

$\beta_{E}$ - wystandaryzowana miara ryzyka rynkowego inwestycji w kapitał własny (akcje) danego przedsiębiorstwa (spółki), tzw. współczynnik beta, $\left(r_{M}-r_{R F}\right)$ - przeciętna premia za ryzyko rynkowe (systematyczne) związane z inwestycjami na danym rynku kapitałowym. Różnica ta określa, o ile przeciętnie jest wyższa stopa zwrotu w aktywa ryzykowne od stopy zwrotu z aktywów wolnych od ryzyka.

Jako stopę wolną od ryzyka w pracy przyjęto średnią rentowność 52-tygodniowych bonów skarbowych w latach 2004-2008 [Wędzki 2003]. Współczynnik beta ustalono dla poszczególnych spółek notowanych na GPW względem indeksu giełdowego WIG w latach 2004-2008 [Notoria Serwis 2008]. Na podstawie studiów literatury przedmiotu premię za ryzyko ustalono jako sumę premii dla rynków europejskich na poziomie $4 \%$ oraz ryzyka kraju (spread) określonego dla Polski na podstawie ratingu kredytowego agencji Fitch w latach 2004-2008 [Fitch Polska 2008].

Dodatkowo oszacowano rentowność kapitału zainwestowanego liczonego jako relacja zysku operacyjnego netto po opodatkowaniu oraz kapitału zainwestowanego z początku okresu.

$$
R O I C_{t}=\frac{N O P A T}{I C_{t B E G}}
$$

gdzie:

$R O I C_{t}$ - stopa zwrotu z zainwestowanego kapitału.

Badania przeprowadzono dla spółek akcyjnych z branży spożywczej notowanych na Giełdzie Papierów Wartościowych w Warszawie w latach 2004-2008. Do badań wykorzystano sprawozdania finansowe analizowanych podmiotów gospodarczych, materiały Głównego Urzędu Statystycznego oraz dane agencji ratingowej Fitch Polska. 


\section{Wyniki badań}

W ujęciu teoretycznym przedsiębiorstwa o agresywnych strategiach płynności finansowej powinny cechować się wyższą wartością dla właścicieli ze względu na dodatni efekt dźwigni finansowej oraz niższy koszt zainwestowanego kapitału. Zastosowanie tego typu strategii oznacza również wzrost ryzyka finansowego w związku ze zwiększeniem zadłużenia oraz ograniczeniem płynności aktywów przedsiębiorstwa. W ramach konserwatywnego podejścia do zarządzania płynnością zakłada się natomiast utrzymanie wysokiej zdolności do regulowania zobowiązań bieżących, co prowadzi do wzrostu nakładów na kapitał obrotowy, zwiększenia kosztu zainwestowanego kapitału a w konsekwencji obniżenia wartości przedsiębiorstwa dla właścicieli. W tabeli 1 przedstawiono średnie znaczenia ekonomicznej i pieniężnej wartości dodanej w grupach przedsiębiorstw o różnych typach strategii płynności finansowej.

Ponadto dokonano dekompozycji omawianych miar wartości dla właścicieli na elementy składowe, pozwalającej na oddzielenie wpływu na wartość poszczególnych parametrów o różnym charakterze: operacyjnym (NOPAT), inwestycyjnym (IC) oraz związanym z finansowaniem (WACC). Teoretycznie realizacja celu w postaci maksymalizacji ekonomicznej wartości dodanej wymaga osiągnięcia maksymalnych zysków operacyjnych, przy akceptowanym przez właścicieli poziomie i koszcie zainwestowanego kapitału.

W badanym okresie najniższe wielkości wskaźnika EVA, obliczanego jako relacja ekonomicznej wartości dodanej do kapitału zainwestowanego, wystapiły w przedsiębiorstwach o strategiach agresywnych. Średnia stopa EVA w tej grupie przedsiębiorstw wynosiła $0,4 \%$ i była o 4,0 p.p. niższa niż w całej badanej zbiorowości. W latach 2004 i 2008 wskaźnik EVA przyjmował ujemne wielkości, co świadczyło o nadwyżce kosztów zainwestowanego kapitału nad zyskiem przedsiębiorstwa z działalności podstawowej. Najwyższe wielkości wskaźnika odnotowano w przedsiębiorstwach o strategiach konserwatywnych, przy czym średnia wielkość wskaźnika w tej grupie spółek była o 9,6 p.p. wyższa od wskaźnika dla strategii agresywnych oraz o 7,1 p.p. dla przedsiębiorstw o strategiach umiarkowanych. Przyczyną takiej sytuacji, sprzecznej z założeniami teoretycznymi koncepcji dochód-ryzyko, były wyższe zyski operacyjne w stosunku do zainwestowanego kapitału oraz niższy średni ważony koszt kapitału tych przedsiębiorstw. Innymi słowy, podmioty gospodarcze o strategiach konserwatywnych charakteryzowały się wyższą efektywnością działalności operacyjnej oraz miały dostęp do tańszych źródeł finansowania.

W przedsiębiorstwach o strategiach agresywnych, charakteryzujących się wyższym poziomem zadłużenia, występowało wyższe ryzyko operacyjne oraz 
Tabela 1

Ekonomiczna wartość dodana oraz pieniężna wartość dodana spółek giełdowych z sektora agrobiznesu w zależności od strategii płynności finansowej

\begin{tabular}{|c|c|c|c|c|c|c|c|c|c|}
\hline \multirow[b]{2}{*}{ Strategia } & \multirow[b]{2}{*}{ Lata } & \multicolumn{8}{|c|}{ Parametr } \\
\hline & & $\begin{array}{c}\text { ROIC } \\
{[\%]}\end{array}$ & $\begin{array}{c}\text { WACC } \\
{[\%]}\end{array}$ & \begin{tabular}{|c|} 
Kapitał \\
zainwestowany \\
na początek \\
okresu [tys. zł]
\end{tabular} & $\begin{array}{c}\text { EVA } \\
\text { [tys. zł] }\end{array}$ & $\mid \begin{array}{c}E V A / I C_{p} \\
{[\%]}\end{array}$ & $\begin{array}{c}\text { Kapitał brutto } \\
\text { zainwestowany } \\
\text { na początek } \\
\text { okresu [tys. zł] }\end{array}$ & $\begin{array}{c}\text { CVA } \\
\text { [tys. zł] }\end{array}$ & $\begin{array}{l}\text { CVA/ } \\
\text { IC [\%] }\end{array}$ \\
\hline \multirow{6}{*}{ A } & 2004 & 4,4 & 8,3 & 614306 & -24095 & $-3,9$ & 678564 & 34832 & 5,1 \\
\hline & 2005 & 6,2 & 6,1 & 392369 & 210 & 0,1 & 433567 & 38886 & 9,0 \\
\hline & 2006 & 12,2 & 6,8 & 500335 & 26961 & 5,4 & 549636 & 72888 & 13,3 \\
\hline & 2007 & 10,1 & 7,5 & 836551 & 22201 & 2,7 & 914795 & 94599 & 10,3 \\
\hline & 2008 & 8,5 & 9,2 & 1473780 & -9639 & $-0,7$ & 1619641 & 122849 & 7,6 \\
\hline & Razem & 8,4 & 8,0 & 3817341 & 15639 & 0,4 & 4196203 & 364046 & 8,7 \\
\hline \multirow{6}{*}{ U } & 2004 & 14,0 & 8,7 & 1271433 & 66639 & 5,2 & 1352125 & 140299 & 10,4 \\
\hline & 2005 & 13,8 & 6,6 & 1411939 & 101453 & 7,2 & 1500685 & 184360 & 12,3 \\
\hline & 2006 & 14,3 & 6,9 & 2384168 & 176155 & 7,4 & 2505634 & 289245 & 11,5 \\
\hline & 2007 & 8,9 & 7,0 & 3397313 & 63700 & 1,9 & 3550316 & 205935 & 5,8 \\
\hline & 2008 & 7,5 & 8,6 & 3969184 & -45622 & $-1,1$ & 4158037 & 126928 & 3,1 \\
\hline & Razem & 10,6 & 7,6 & 12434037 & 362325 & 2,9 & 13066796 & 946748 & 7,2 \\
\hline \multirow{6}{*}{$\mathrm{K}$} & 2004 & 14,4 & 8,9 & 437234 & 24424 & 5,6 & 461280 & 46338 & 10,0 \\
\hline & 2005 & 10,2 & 6,4 & 1019591 & 38317 & 3,8 & 1073529 & 88792 & 8,3 \\
\hline & 2006 & 11,9 & 7,5 & 620513 & 27191 & 4,4 & 662218 & 65780 & 9,9 \\
\hline & 2007 & 29,5 & 7,3 & 1478495 & 327343 & 22,1 & 1542956 & 387079 & 25,1 \\
\hline & 2008 & 14,5 & 7,1 & 2450190 & 181696 & 7,4 & 2526519 & 252586 & 10,0 \\
\hline & Razem & 17,2 & 7,2 & 6006022 & 598970 & 10,0 & 6266501 & 840648 & 13,4 \\
\hline \multirow{6}{*}{ Ogółem } & 2004 & 11,5 & 8,6 & 2322973 & 66967 & 2,9 & 2491969 & 221469 & 6,2 \\
\hline & 2005 & 11,4 & 6,5 & 2823899 & 139980 & 5,0 & 3007780 & 312039 & 11,0 \\
\hline & 2006 & 13,6 & 7,0 & 3505016 & 230308 & 6,6 & 3717488 & 427913 & 12,2 \\
\hline & 2007 & 14,4 & 7,2 & 5712359 & 413244 & 7,2 & 6008067 & 687613 & 12,0 \\
\hline & 2008 & 9,9 & 8,3 & 7893153 & 126435 & 1,6 & 8304196 & 502363 & 6,4 \\
\hline & Łącznie & 12,0 & 7,6 & 22257400 & 976934 & 4,4 & 23529500 & 2151441 & 9,7 \\
\hline
\end{tabular}

Źródło: Opracowanie własne.

finansowe. W spółkach o strategiach agresywnych średnia wielkość wskaźnika ROIC była o 8,8 p.p. niższa, a kosztu kapitału (WACC) o 0,8 p.p. wyższa niż w grupie przedsiębiorstw o strategiach konserwatywnych. Z jednej strony niższy poziom zysku operacyjnego był spowodowany wysokimi kosztami prowadzonej działalności, co skutkowało obniżeniem stopy zwrotu z zainwestowanego kapitału. Z drugiej strony, można przypuszczać, że w spółkach o strategiach 
agresywnych wyższy koszt kapitału wynikał z efektu neutralizacji korzyści z tytułu zwiększenia udziału obcego kapitału krótkoterminowego w strukturze finansowania: właściciele zainwestowanego kapitału żądali wyższej stopy zwrotu ze względu na wysokie ryzyko operacyjne, a niedobór źródeł finansowania prowadził do pojawiania się kosztów trudności finansowych. Taka sytuacja może być thumaczona występowaniem zależności między dochodem a ryzykiem (risk-return trade-off), zgodnie z którą racjonalny inwestor wymaga wyższej premii $\mathrm{z}$ zainwestowanego kapitału $\mathrm{w}$ miare wzrostu poziomu ryzyka. Zatem $\mathrm{w}$ przedsiębiorstwach o strategiach agresywnych wyższa premia za ryzyko powinna być wypłacana z ponadprzeciętnych zysków osiaganych na skutek wyższej dochodowości działalności operacyjnej oraz działania mechanizmu tarczy podatkowej. W badanej grupie podmiotów gospodarczych o agresywnych strategiach płynności finansowej wzrost ryzyka nie przekładał się na zwiększenie zysków z działalności operacyjnej, a wzrost kosztu kapitału ograniczał zyskowność ekonomiczną. Świadczyło to o niskim poziomie efektywności tych przedsiębiorstw w segmentach operacyjnym i finansowym.

Obliczenie pieniężnej wartości dodanej (CVA) dla badanych przedsiębiorstw potwierdziło wniosek o niższej efektywności przedsiębiorstw z grupy strategii agresywnych. W tych spółkach średni wskaźnik pieniężnej wartości dodanej obliczony jako iloraz zysku rezydualnego do kapitału zainwestowanego brutto wzrósł do $8,7 \%$, z kolei w przedsiębiorstwach o strategiach konserwatywnych - do 13,4\%. Znaczący wzrost wskaźnika pieniężnej wartości dodanej w stosunku do wskaźnika EVA świadczył o dużym udziale amortyzacji w przepływach operacyjnych przedsiębiorstw o strategiach agresywnych. W krótkim okresie wyższy strumień przepływów operacyjnych owocował szybszym przyrostem wartości dla właścicieli, z kolei $\mathrm{w}$ długim horyzoncie czasowym nie wpływało to na zwiększenie wartości przedsiębiorstwa dla właścicieli, gdyż przepływy z tytułu amortyzacji były wykorzystywane na odtworzenie majątku przedsiębiorstwa w celu utrzymania produkcji na dotychczasowym poziomie. Oznaczało to wyższe inwestycje w zasoby przedsiębiorstwa, a także wzrost kosztów kapitału. Należy stwierdzić, że w długim horyzoncie czasowym jedynie zysk operacyjny był źródłem zwiększenia wartości przedsiębiorstwa dla właścicieli. W takim ujęciu trzeba zaznaczyć przewagę klasycznej miary ekonomicznej wartości dodanej nad wartością pieniężną, gdyż obrazuje ona rzeczywistą nadwyżkę uzyskanych korzyści nad wszystkimi kosztami prowadzonej działalności, niezależnie od charakteru i miejsca powstawania tych kosztów.

Graficznie omawiane zależności między osiaganą wartością dla właścicieli a strategią płynności finansowej poszczególnych spółek akcyjnych z sektora agrobiznesu przedstawia rysunek 1 . Oś wartości X prezentuje kształtowanie się wskaźnika płynności bieżącej, charakteryzując nastawienie na maksymalizację 
płynności finansowej. Na osi pionowej przedstawiono wskaźnik ekonomicznej wartości dodanej (EVA/IC), tzn. nastawienia na kreację wartości dla właścicieli. Przedsiębiorstwa o różnych typach strategii istotnie różniły się między sobą poziomem płynności finansowej, nie zauważono natomiast znaczących wahań wskaźników ekonomicznej wartości dodanej wraz ze wzrostem ryzyka płynności. W spółkach o strategiach agresywnych omawiany wskaźnik przyjmował przeważnie ujemne lub niskie dodatnie wielkości. W przypadku przedsiębiorstw o strategiach konserwatywnych notowano wyższe wskaźniki ekonomicznej wartości dodanej.

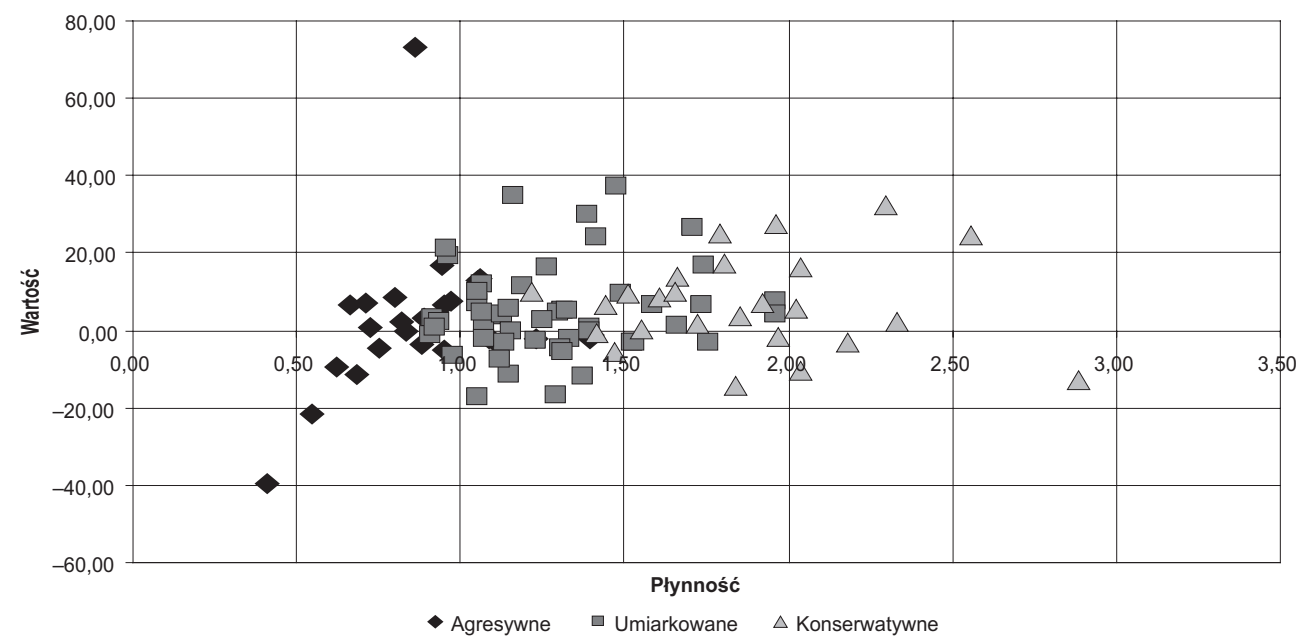

\section{Rysunek 1}

Relacja między osiagganą wartością przedsiębiorstwa dla właścicieli [\%] a płynnością finansową w zależności od strategii płynności finansowej spółek akcyjnych z sektora agrobiznesu

Źródło: Opracowanie własne.

W ujęciu liczbowym stosunkowo największą efektywnością ekonomiczną wykazywały się przedsiębiorstwa o strategiach konserwatywnych, gdyż $72 \%$ obserwacji charakteryzowało się dodatnią wielkością wskaźnika ekonomicznej wartości dodanej (tab. 2).

W grupie przedsiębiorstw o strategiach agresywnych dodatnią wielkość tego wskaźnika odnotowano w 48\% przypadków, czyli o 18 p.p. mniej niż w grupie spółek o strategiach umiarkowanych. W przedsiębiorstwach o strategiach konserwatywnych odnotowano stosunkowo najmniej obserwacji o ujemnym wskaźniku EVA/IC w granicach $0-(-10 \%)$ oraz najwięcej o dodatnim wskaźniku w przedziale $0-10 \%$. Ponadto, w tej grupie spółek odnotowano wyższy 
Tabela 2

Wartość wskaźnika ekonomicznej wartości dodanej (EVA/IC) w zależności od strategii płynności finansowej spółek giełdowych z sektora agrobiznesu

\begin{tabular}{|l|c|c|c|c|c|c|}
\hline \multirow{2}{*}{ Przedział } & \multicolumn{6}{|c|}{ Strategia } \\
\cline { 2 - 7 } & \multicolumn{2}{|c|}{ agresywna } & \multicolumn{2}{c|}{ umiarkowana } & \multicolumn{2}{c|}{ konserwatywna } \\
\cline { 2 - 7 } & liczba & udział [\%] & liczba & udział [\%] & liczba & udział [\%] \\
\hline$>20 \%$ & 1 & 4,0 & 7 & 14,0 & 4 & 16,0 \\
\hline $10-20 \%$ & 3 & 12,0 & 6 & 12,0 & 3 & 12,0 \\
\hline $0-10 \%$ & 8 & 32,0 & 20 & 40,0 & 11 & 44,0 \\
\hline$(-10)-0 \%$ & 10 & 40,0 & 13 & 26,0 & 4 & 16,0 \\
\hline$(-10)-(20) \%$ & 1 & 4,0 & 4 & 8,0 & 3 & 12,0 \\
\hline Powyżej $(-20) \%$ & 2 & 8,0 & 0 & 0,0 & 0 & 0,0 \\
\hline Ogółem & 25 & 100,0 & 50 & 100,0 & 25 & 100,0 \\
\hline EVA/IC >0 & 12 & 48 & 33 & 66 & 18 & 72 \\
\hline EVA/IC < 0 & 13 & 52 & 17 & 34 & 7 & 28 \\
\hline
\end{tabular}

Źródło: Opracowanie własne.

udział przypadków osiągnięcia ponadprzeciętnych (powyżej 20\%) zysków ekonomicznych na poziomie 16\% wszystkich obserwacji. W grupie przedsiębiorstw o strategiach agresywnych odnotowano dwa przypadki osiagnięcia skrajnych strat ekonomicznych ( $8 \%$ obserwacji) oraz tylko jeden ponadprzeciętnych zysków ekonomicznych (4\% obserwacji). W ramach strategii konserwatywnej stratę ekonomiczną na poziomie 10-20\% wykazywało $12 \%$ obserwacji, o 8 p.p. więcej niż w strategiach agresywnych.

Reasumując, należy stwierdzić, że grupa przedsiębiorstw o strategiach konserwatywnych charakteryzowała się wyższą zdolnością do generowania wartości dla właścicieli, przy wyższym poziomie płynności finansowej. O większym prawdopodobieństwie osiągnięcia ponadprzeciętnych zysków w tej grupie przedsiębiorstw świadczyły wyniki analizy zarówno zagregowanych wskaźników dla grup, jak i badanie rozkładu wskaźnika ekonomicznej wartości dodanej w poszczególnych spółkach badanej próby. Wyższe stopy zwrotu z zainwestowanych kapitałów w przedsiębiorstwach o strategiach konserwatywnych można wyjaśnić za pomocą teorii hierarchii źródeł finansowania. Zgodnie z założeniami tej teorii w przedsiębiorstwach o dużej zdolności do generowania gotówki musiało następować zatrzymanie znaczącej części wypracowanych zysków, co determinowało zmianę struktury kapitałowej spółek giełdowych w kierunku bardziej konserwatywnej. Oznaczałoby to, że poziom rentowności przedsiębiorstw w dużym stopniu warunkował stosowane strategie płynności finansowej. Takie wnioski znajdują swoje uzasadnienie w licznych badaniach empirycznych, 
które dowiodły, że przedsiębiorstwa wypracowujące wysokie zyski reinwestują je i zachowują stosunkowo niskie wskaźniki zadłużenia [Franc-Dąbrowska 2007, s. 163].

\section{Wnioski}

Na podstawie przeprowadzonych w artykule badań sformułowano następujące wnioski:

1. Spółki giełdowe o konserwatywnych strategiach płynności finansowej charakteryzowały się wyższą efektywnością ekonomiczną. Przyczyną takiej sytuacji było osiagnięcie wyższych w stosunku do innych grup spółek stóp zwrotu z prowadzonej działalności operacyjnej, przy relatywnie niższych kosztach zainwestowanego kapitału. Należy zaznaczyć, że możliwość kreowania maksymalnych korzyści dla właścicieli tych przedsiębiorstw była ograniczona nadmiernym poziomem inwestycji w majątek obrotowy oraz dużym udziałem kapitałów stałych w strukturze finansowania.

2. W badanej zbiorowości odnotowano tendencję do obniżenia się poziomu efektywności przedsiębiorstwa, wraz ze wzrostem stopnia agresywności strategii płynności finansowej. Oznacza to, że wyższemu ryzyku utraty płynności finansowej towarzyszyły niższe wskaźniki rentowności oraz wartość przedsiębiorstw dla właścicieli. Należy zaznaczyć, że warunkiem wyższej wartości przedsiębiorstwa dla właścicieli w ramach strategii agresywnej było osiagnięcie ponadprzeciętnych zysków z działalności operacyjnej, przy zmniejszeniu kosztów kapitału. Spełnienie tego warunku było możliwe dzięki wykorzystaniu efektu dźwigni operacyjnej, a także ukształtowaniu optymalnej struktury kapitału w spółkach. W warunkach podwyższonego ryzyka inwestycji nadmierne ograniczenie aktywów obrotowych w stosunku do aktywów trwałych, a także obniżenie poziomu kapitału obrotowego netto, jakie występowało w ramach strategii agresywnej, mogło skutkować zmniejszeniem możliwości produkcyjnych, a zatem przychodów ze sprzedaży oraz doprowadzić do powstawania ujemnych efektów dźwigni operacyjnej. Z kolei nadmierny udział zadłużenia w strukturze finansowania powodował wzrost wymaganej przez inwestorów stopy zwrotu z zainwestowanego kapitału, co w warunkach niskich zysków operacyjnych determinowało straty ekonomiczne. Wskazywało to na trudność osiągnięcia wyższej wartości przedsiębiorstwa dla właścicieli przy zastosowaniu agresywnej strategii płynności finansowej w spółkach giełdowych z branży spożywczej.

3. W ramach strategii płynności finansowej realizacja nadrzędnego celu działalności przedsiębiorstwa w postaci systematycznego zwiększania wartości 
dla właścicieli wymagała maksymalizacji przepływów pieniężnych z tytułu działalności operacyjnej, przez aktywizację sprzedaży oraz zsynchronizowanie procesu zarządzania płynnością finansową $w$ aspekcie finansowania natomiast - ukształtowania optymalnej, z punktu widzenia jednostki gospodarczej, relacji kapitału własnego do kapitałów obcych, umożliwiającej minimalizację średniego ważonego kosztu kapitału.

\title{
Literatura
}

Franc-Dąbrowska J., 2010: Teoretyczne i praktyczne aspekty gospodarowania zyskiem w przedsiębiorstwach rolniczych. Wydawnictwo SGGW, Warszawa.

Franc-Dąbrowska J., 2007: Wypłaty pieniężne z zysku a płynność finansowa w przedsiębiorstwach agrobiznesu. Prace Naukowe Akademii Ekonomicznej we Wrocławiu nr 1174, Rachunkowość a Controlling, Wrocław.

Rappaport A., 1999: Wartość dla akcjonariuszy - poradnik menadżera i inwestora. WIG Press, Warszawa.

Sierpińska M., Wędzki D., 1997: Zarzadzanie plynnościa finansowa w przedsiębiorstwie. Wydawnictwo Naukowe PWN.

StatSoft Polska, 2009: Analizy wielowymiarowe. Materiaty kursowe. StatSoft Polska, Kraków. Wędzki D., 2003: Strategie płynności finansowej przedsiębiorstwa. Oficyna Ekonomiczna, Kraków, s. 34.

Wasilewski M., Zabolotnyy S., 2009: Efektywność strategii zarzadzania kapitałem obrotowym $w$ spółkach giełdowych z branży spożywczej. Makroekonomiczne uwarunkowania rozwoju gospodarki żywnościowej. Wydawnictwo SGGW, Warszawa.

Wasilewski M., Zabolotnyy S., 2009: Sytuacja finansowa przedsiębiorstw o odmiennych strategiach zarzadzania kapitałem obrotowym. Zeszyty Naukowe SGGW. Ekonomika i Organizacja Gospodarki Żywnościowej, nr 78, Warszawa.

http://www.fitchpolska.com.pl/

http://ir.notoria.pl/

\section{Economic value depending on the strategy of liquidity of joint-stock companies from the agribusiness sector listed on Warsaw Stosk Exchange}

\begin{abstract}
The aim of the research was to identify the dependence between strategies of liquidity and effectiveness of joint-stock companies from agribusiness sector. Joint-stock companies with conservative strategies of liquidity were characterized by higher economic effectiveness. The reason for such a situation were higher rates of return from operations as well as comparatively lower cost of capital
\end{abstract}


in these companies. It was noticed the decrease of the level of effectiveness accompanying the growth of the aggressiveness of strategies of liquidity. This means that the higher risk of liquidity led to lower ratios of profitability and shareholders' value. 